DOI: https://doi.org/10.46991/AFA/2021.17.2.129

\title{
THE EASTERN PHILOSOPHER AND THE WESTERNIZED PROPHET
}

\author{
Vicky Tchaparian* \\ Lebanese University
}

\begin{abstract}
Gibran Khalil Gibran is one of the few Lebanese authors who has bridged the East and the West and is justifiably considered a citizen of the world. His book of highly estimated prose poems, The Prophet is one of the most widely read books of the $20^{\text {th }}$ century. It reveals Gibran's philosophy about different aspects of life, mainly the precept in the Gospel of Matthew about the importance of the human sense of mutuality which summarizes a Christian's duty towards his/her neighbor and states a fundamental ethical principle. In addition to this golden rule, The Prophet reflects Gibran's beliefs in Christianity. Being a true mirror of the Sufi mysticism of Islam, it also shows his idealistic opinion on pantheism. From this perspective, the research will focus on the combination of his beliefs in Christianity, Islam, and pantheism in The Prophet, as well as his firm conviction in creating the united and unique structure of a Christian-Muslim synthesis which he deeply adhered to.
\end{abstract}

Keywords: Christianity, the Gospel, Sufi, Islam, the Quran, pantheism, Prophet Almustafa, East and West.

\section{Introduction}

Gibran Khalil Gibran, a pioneer in the world of literature and philosophy, born in Bsharri, North Lebanon towards the end of the $19^{\text {th }}$ century, was of poor parentage, and suffered chaos and struggles throughout his life. He migrated to the States at an early age, and on a turning point in his life, when he was twenty-one. In Boston, at a friend's studio, he encountered a benevolent called Mary Elizabeth Haskell who changed his life forever. Mrs. Haskell, a philanthropist and patron of arts, was so impressed with Gibran's skill in arts that she sent him to Paris to study painting, paying his full scholarship. Later, 
she edited and published all his books encouraging him to dive deeper not only in painting but also in literature and philosophy.

Later in his writing career, Kahlil Gibran not only made Mary Haskell's wish come true, but also became one of the most commercially successful poets of the $20^{\text {th }}$ century. His works are read internationally, especially his masterpiece, The Prophet, which has been translated into more than 100 different languages and dialects, making it one of the top translated books of all time.

Gibran was a Lebanese Arab, so his mother tongue was the Arabic language. However, living in the United States, he also wrote in English, thus becoming a bilingual writer. Some of his works are written in English and some others in Arabic, but all his works have been translated to both languages. By the time he wrote The Prophet, Gibran had become a prolific writer in both Arabic and English. He was an accomplished illustrator and artist, and the president of the New York based Arab émigré writers group. He was also one of the four members of the Pen League (a group of writers who helped preserve the heritage of early immigrant poets such as Mikhael Naimy, Nasib Arida, Abd Al-Masih Haddad, Jaoudat Haidar, and Elia Abu Madi).

The Prophet occupies a unique place in world literature. It is a work of remarkable compassion, insight, hope, and inspiration. It has a timeless message that combines the dignity of Christianity and the wisdom of Sufism (Oxford Islamic Studies Online, 2021). Receiving a copy of The Prophet, in October 1923, Mary Haskell prophesized its success saying "this book will be held as one of the treasures of English literature. And in our darkness we will open it to find ourselves again, and the heaven and earth within ourselves. Generations will not exhaust it, but instead, generation after generation will find in the book what they would like to find - and it will be better loved as we grow riper and riper" (Hilu, 1972, pp. 416-417).

The book consists of twenty-six poems recited by Almustafa, a prophet in the city of Orphalese. The short poems refer to different themes such as love, marriage, children, eating and drinking, work, joy and sorrow, clothes, buying and selling, crime and punishment, laws, freedom, reason and passion, pain, self-knowledge, teaching, friendship, talking, time, good and evil, prayer, pleasure, beauty, religion, and death. Nearly in one hundred years The Prophet was sold in millions of copies worldwide, and never went out of print (Sammons, 2014). 
Although The Prophet was not effectively completed until 1922, when Gibran was plagued with ill health, his first thought of writing The Prophet had been in his teens. In a letter to May Ziadeh, his Lebanese pen pal, whom he had never met, yet dearly loved, Khalil Gibran had confessed:

As for The Prophet, this is a book which I thought of writing a thousand years ago, but I did not get any of its chapters down on paper until the end of last year. What can I tell you about this prophet? He is my rebirth and my first baptism, the only thought in me that will make me worthy to stand in the light of the sun. For this prophet had already written me before I attempted to write him, had created me before I created him, and had silently set me on a course to follow him for seven thousand leagues before he appeared in front of me to dictate his wishes and inclinations (cited in Bushrui \& al-Kuzbari,1995, p. 23). This book is only a small part of what I have seen and of what I see every day, a small part only of the many things yearning for expression in the silent hearts of men and in their souls (ibid., p. 73).

The questions which may now be raised to discuss Gibran's work are: Does The Prophet reveal Gibran's adherence to the West where he lived or his adherence to his Eastern origin? Does the Prophet disclose Gibran's pantheism? Is the Prophet Almustafa a Christian Messiah or a Sufi Muslim? These questions will be answered by exploring Gibran's idealism (related to his cultural identity torn between the East and the West), his Christian and Muslim perceptions, and his pantheism.

\section{Gibran's cultural identity torn between the East and the West}

Throughout his masterpiece, The Prophet, Gibran bridges the East and the West. In the East, in the Arabic-speaking world, he is considered the genius of his age, while in the West Gibran's works have been compared to those of Blake, Dante, Tagore, Nietzsche, Michelangelo, and Rodin (Bushrui, 2015). Gibran's popularity as an oriental writer is unprecedented, and along with the works of T. S. Eliot and W. B. Yeats, The Prophet is today the most highly regarded poem of the twentieth century (ibid.). 
Being a Lebanese Maronite Christian, the Bible (King James Version (KJV), 1994) has been Gibran's inexhaustible source of influence (Bushrui \& Jenkins, 1998). However, Gibran, as an Arab, was also influenced by Sufism which is a form of mysticism in Islam and is often referred to as the internalization and intensification of Islamic faith and practice. Sufis strive to constantly be aware of God's presence, stressing contemplation over action, spiritual development over legalism, and cultivation of the soul over social interaction (Oxford Islamic Studies Online, 2021).

It was Gibran's knowledge of Lebanon's bloody history with its destructive sectarian struggles between the Christians and the Muslims that formed his belief in the fundamental unity of religions (Jason, 2003) creating in him a new character - the Christian Sufi.

In a city that lay between the sea and the plains, a prophet called Almustafa wandered in the fields and among the people. He was a poet, a seer, and someone who loved all the people in the city and whom they all loved, old and young. As he moved around, young women got obsessed by him, yet no woman dared to fall in love with him. The priests and priestesses said: "Much have we loved you. But speechless was our love, and with veils has it been veiled" (Gibran, 1923, p.13). Though people considered him a part of the city, yet they all had the consciousness that his existence among them was temporary and the day of his departure was soon to arrive. Every day the prophet waited for the distant ship, but the ship did not appear. "Almustafa, the chosen and the beloved, who was a dawn unto his own day, had waited twelve years in the city of Orphalese for his ship that was to return and bear him back to the isle of his birth" (ibid., p.7). He longed for his home, and waited for twelve years to leave Orphalese. On the day of the prophet's departure the seeress Almitra told him: "Deep is your longing for the land of your memories and the dwelling place of your greater desires; and our love would not bind you nor our needs hold you" (ibid., p. 14). So, when out of the blue horizon, the ship came towards the city, everyone knew that the ship was for the hermit.

Prophet Almustafa's longing for the ship to take him away, can be compared to Gibran's longing for the East during his life in the West. In fact, due to their circumstances as exiles, most of the Mahjar poets wrote about their feelings of homesickness, their awareness of being outsiders, and their dual cultural experience (Badawi, 1975, p.184). Gibran loved the West which had raised him from his poverty and had given him a new life with new promises but, as he stated, the West was not higher than the East, nor was the West lower 
than the East (Gibran, 2015). Thus, he asserted his adherence to the East without denying his admiration for the West. His yearning for the East (especially for Lebanon) and his Lebanese heritage made him declare that if Lebanon had not been his homeland, he would have chosen that country for a homeland. Yet the Lebanon that Gibran created in his mindset, was completely different from the real Lebanon. Thus, he wrote in his poem:

You have your Lebanon and its dilemma. I have my Lebanon and its beauty. Your Lebanon is an arena for men from the West and men from the East...

Let me tell you who are the children of my Lebanon.

They are farmers who would turn the fallow field into garden and grove.

They are the shepherds who lead their flocks through the valleys to be fattened for your table meat and your woolens.

They are the vine-pressers who press the grape to wine and boil it to syrup...

They are the ones who are steadily moving toward perfection, beauty, and truth.(Gibran, 1920)

Therefore, with all his love that was torn between the East and the West, Gibran always remained an easterner in manners and a Lebanese in his feelings with a unique "Lebanon" belonging to him and dwelling in his mind and in his heart.

\section{Is Gibran's Prophet Almustafa - a Christian Messiah or a Sufi Muslim?}

Bushrui and Jenkins (1998) consider The Prophet, a work of remarkable compassion, insight, hope, and inspiration, with a timeless message that combines the dignity of the Christian Bible with the wisdom of the Sufism of Islam, a creation phrased with simplicity and rhythmical quality that renders it accessible to a wide readership, making it a masterpiece of all times. The book owes its broad appeal partly to the universality and timelessness of its message and partly to the power of its poetry representing an appeal for a return to, and a reconciliation with nature, emphasizing the relationship that binds individuals to their environment and fellow creatures. Gibran makes them all become the inhabitants of the one and only world bound together by life and death. Accordingly, 
Those who err are not alone, and those who reach the sublime heights share it with all; our destiny lies in the way we act toward one another, and the salvation of the individual is the salvation of the society. Thus Almustafa sets out his own version of the golden rule common to all great religions: that we must do as we would be done by.(ibid.)

It is clear that Prophet Almustafa emphasized the golden rule (to do others what you would like them do to you) as common in most of the great religions. It is a fact that Prophet Almustafa himself was a combination of Christianity and Islam mingled together in an artistic form. To prove this right, I will mention different verses from both the Christian Holy Gospel as well as the Islamic Holy Quran that reveal the golden rule in which Gibran's Almustafa believed. For example, the Gospel of Mathew says: "Judge not, that ye be not judged. For with what judgment ye judge, ye shall be judged: and with what measure ye mete, it shall be measured to you again" (Mathew, 7:1-3, KJV). Another verse from the same Gospel says, "Therefore all things whatsoever ye would that men should do to you, do ye even so to them: for this is the law and the prophets" (Mathew, 7:12, KJV). Moreover, the Gospel of Luke says: "And as ye would that men should do to you, do ye also to them likewise (Luke, 6:31, KJV). It also says: "Judge not, and ye shall not be judged: condemn not, and ye shall not be condemned: forgive, and ye shall be forgiven" (Luke, 6:37, KJV). All these verses from the Gospel reveal the same golden rule which Gibran's Almustafa believed in.

In the Holy Quran this golden rule is revealed in many occasions and in different suras (chapters). For example, the sura of The Imrans says: "The day will surely come when each soul will be confronted with whatever good it has done. As for its evil deeds" (The Imrans, 3:30). The Sura of The Earthquake says: "On the day mankind will come in broken bands to be shown their labors. Whoever does an atom's weight of good shall see it, and whoever does an atom's weight of evil shall see it also" (The Earthquake, 8:7). The sura of The Cow says: "Attend to your prayer and pay the alms-tax. Whatever good you do shall be rewarded by Allah. He is watching over all your actions" (The Cow, 2: 110). The sura of The Clear Proof says: "But those that embrace the faith and do good works are the noblest of all creatures. Allah will reward them with the Gardens of Eden, gardens watered by running streams, where they shall dwell 
forever. Allah is well pleased with them and they with Him. Thus shall the God-fearing be rewarded" (The Clear Proof, 98:8).

Thus, it is clear that both the Gospel and the Quran have included the golden rule of doing to others as you would like to be done to. Other forms of this rule include doing good and getting rewarded, doing bad and being punished. It is also clear that Gibran's Almustafa is both a Christian Messiah and a Sufi Muslim. As Gibran once declared, he himself kept Jesus in one half of his bosom and Muhammad in the other (cited in Sammons, 2014). Apparently, Prophet Almustafa (one of the names also given to Prophet Muhammad), symbolizes a union of Christianity (which is Gibran's religion at birth) and Islam (to which Gibran was so closely related).

\section{The Prophet and Gibran's pantheism}

For Gibran, the East and the West, the pagan and the believer in God, the ancient and the modern, the past and the present come together to reaffirm his faith in the unity of being. Thus, along with his Christian and Islamic beliefs, The Prophet reveals some of his beliefs in pantheism, which is the keynote of The Prophet, as is in much of the works of the Romantic poets. Like all great writers, Gibran endeavors to show how opposites can be reconciled (Bushrui \& Jenkins, 1998). Thus, Prophet Almustafa speaks of different opposites such as the good and the evil, joy and sorrow, life and death, past and present, and eve and dawn. Speaking of the good and the evil, for example, Prophet Almustafa says:

You are good when you are one with yourself.

Yet when you are not one with yourself you are not evil.

For a divided house is not a den of thieves; it is only a divided house.

And a ship without rudder may wander aimlessly among perilous isles yet sink not to the bottom.

You are good when you strive to give of yourself.

Yet you are not evil when you seek gain for yourself.

Yet when you are not one with yourself you are not evil.

(Gibran, 1923, p.73)

Moreover, Gibran believes that joy and sorrow are not only opposites, but they also feed on each other, hence, Almustafa says: 
Your joy is your sorrow unmasked...

When you are joyous, look deep into your heart and you shall find it is only that which has given you sorrow that is giving you joy.

When you are sorrowful look again in your heart, and you shall see that in truth you are weeping for that which has been your delight. (ibid., pp. 35- 36)

For Gibran, life and death are sources of one another. Thus the prophet says:

You would know the secret of death.

But how shall you find it unless you seek it in the heart of life?

The owl whose night-bound eyes are blind unto the day cannot unveil the mystery of light.

If you would indeed behold the spirit of death, open your heart wide unto the body of life.

For life and death are one, even as the river and the sea are one.(ibid., p. 90)

Furthermore, for Gibran, the ancient and the modern, as well as the past and the present come together to reaffirm his faith in the unity of being. Thus speaking of time, Almustafa says:

You would measure time the measureless and the immeasurable.

You would adjust your conduct and even direct the course of your spirit according to hours

and seasons.

Of time you would make a stream upon whose bank you would sit and watch its flowing.

Yet the timeless in you is aware of life's timelessness,

And knows that yesterday is but today's memory and tomorrow is today's dream.(ibid., p.70)

Likewise, he says of parting and gathering, as well as of eve and dawn: "Shall the day of parting be the day of gathering? And shall it be said that my eve was in truth my dawn?" (ibid., p. 10). He believes in oneness of the whole 
world. The poet who is speaking in the voice of the hermit Almustafa is himself the representative of the reconciliation of all these opposites at all levels. Moreover, like the romantic poets, Gibran also believes in the idea of transcendentalism. For him, every man is a longing - the longing of the divine. Every man bears within him the longing and the fulfillment which is God, and the road leading to this fulfillment. As Gibran tells his soulmate, Mary Haskell, "the whole prophet is saying just one thing: you are far greater than you know, and all is well" (Gibran, 2020).

Along with his belief in transcendentalism, the keynote of the prophet, as mentioned above, is pantheism (Bushrui, 2012). Pantheism has the view that everything is part of an all-encompassing, immanent God. It is the belief of reality identical with divinity, the belief in God. Moreover, the central belief in pantheism is that God is latent within everyone as a Greater Self, and that this is attained through aspiration, or yearning, which is comparable to prayer in religion, and through successive reincarnations. Life is a journey, and God is both the starting point and the destination (ibid.). This idea is revealed when hermit Almustafa is asked about crime and punishment and he tells the people of Orphalese: "... as a single leaf turns not yellow but with the silent knowledge of the whole tree, So the wrong-doer cannot do wrong without the hidden will of you all. Like a procession you walk together towards your god-self" (Gibran, 1923, p. 49).

It is worth mentioning that the Gospel of Psalm gives almost the same meaning when it says, "the earth is the Lord's, and the fullness thereof, the world and they that dwell therein" (Psalm, 24:1, KJV). Thus, according to the Gospel, God is the creator of the earth and all that dwells in it. Whilst, in the Sura of Divorce, the Quran says: "It is Allah who has created seven heavens and earths as many. His commandment descends through them, so that you may know that Allah has power over all things and that he has knowledge of all things" (Divorce, 65:12). Like in the Gospel, the Quran says that God is the sovereignty and supremacy of the heavens and the earth and all that is between them, and unto him is the journeying. The journeying represents the condition of full awareness when the soul has embarked on the path leading to its desired union with God, and the enlightened wayfarer Almustafa offers directions for anyone who would undertake such a journey (Bushrui, 2012).

Thus, a man's journey in life represents the embankment and escalation on the path leading towards the unity of the soul with God Almighty, Creator of heaven and earth. Implicit here is Ibn Al-Arabi's Sufistic theory of journeying 
towards God Almighty and the unity of religions. To him revelation is universal and every prophet has transmitted an aspect of God's will to humankind. Therefore, if we examine the inner contents of all religions by journeying inwardly from the external forms towards the inner one, we will find a transcendent unity that they all emanate from the same supreme center (ibid.).

It can be concluded that The Prophet reveals Gibran's solitude in pantheism to which the Gospel, The Quran, and Ibn Al Arabi's sufistic theory all point.

\section{Conclusion}

Thus, it can be deduced that Gibran's torn cultural identity which is a mixture of the Maronite Christian and the Sufi Arab, helps him create Prophet Almustafa who is a manifestation of Gibran himself, a combination of the East and the West, an Arab in origin and an American in nationality. It can also be inferred that The Prophet summarizes Gibran's philosophy of life along with his mature ideas related to Christianity and Islam which create a ChristianMuslim synthesis. Throughout The Prophet Gibran reveals a unique being who is both a Christian Messiah and a Sufi Muslim with an eastern identity armed with the doctrine of pantheism. Accordingly, through his curio, Gibran proves himself to be the Christian poet as well as the Sufi prophet lost in the dilemma of his eastern solitude producing a masterpiece that has so far occupied an unparalleled and unique place in world literature.

\section{References}

Badawi, M. (1975). A critical introduction to modern Arabic poetry. Cambridge: Cambridge University Press.

Bushrui, S., \& Al-Kuzbari, S. H. (1995). Love letters. England: Oneworld Publications.

Bushrui, S., \& Jenkins, J. (1998). Kahlil Gibran, man and poet: a new biography. England: Oneworld Publications.

Bushrui, S. B. (2012). Gibran Khalil. The Prophet: a new annotated edition. England: Oneworld Publications,.

Bushrui, S. (2015). Man \& poet. The Khalil Gibran collective. Retrieved February 16, 2021 from https://www.kahlilgibran.com/digital-archive.html? limit $=20 \&$ limitstart $=500$ www.khalilgibran.com. 
Gibran, Kh. (2015). Secrets of the heart: selected works by Khalil Gibran.

(A.R. Ferris, Trans.). New York: Taico Publishing House.

Gibran, Kh. (1920). You have your Lebanon and I have my Lebanon. M. L.

Wolf, A. R. Ferris, \& A. D. Sherfan (Eds. and Trans.). Retrieved

December 18, 2020, from http://4umi.com/gibran/lebanon/

Hilu, V.(Ed). (1972). Beloved prophet: the love letters of Kahlil Gibran and Mary Haskell, and her private journal, New York: Knopf, 416-417;

Jason, Ph. (2003). Critical survey of poetry. V. 3., Pasadena: Salem Press.

Oxford Islamic studies online. (2021). Retrieved from http://www.oxfordislamicstudies.com/Public/Home.html?url=\%2Fapp\%3Fservice\%3Dexter nalpagemethod $\% 26$ method $\% 3$ Dview $\% 26$ page $\% 3$ DHome $\&$ failReason $=$

Sammons, J.T. (2014). The enduring legacy of Kahlil Gibran. USA: University of Maryland.

The Holy Bible. $21^{\text {st }}$ Century King James Version (KJ21). (1994). $21^{\text {st }}$ Century King James Bible Publishers.

The Holy Quran. (1980). Beirut: Dar Al- Choura.

\section{Sources of Data}

Gibran, Kh. (1923). The Prophet. New York: Knopf.

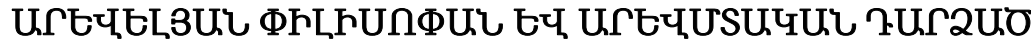 UURqurEל}

\section{Чhph 2uuhupturu}

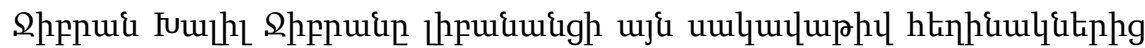

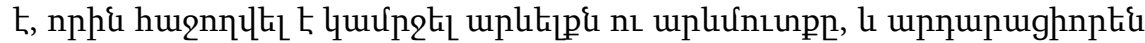

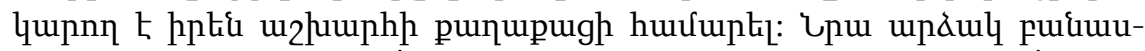

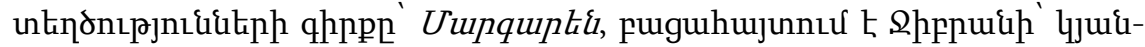

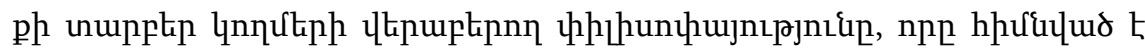

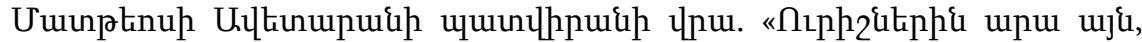

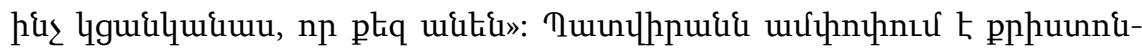

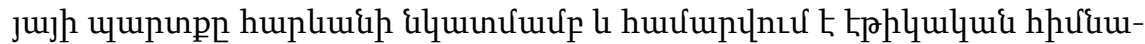

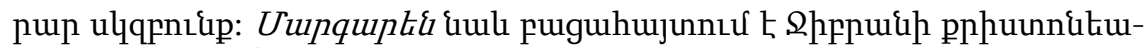

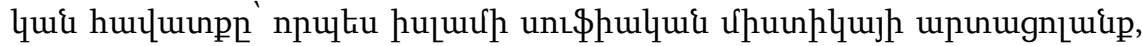

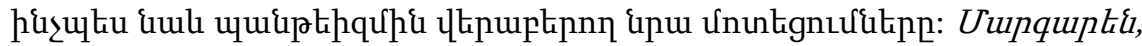

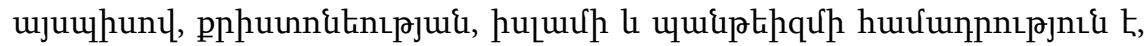




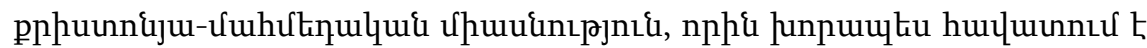
Shppuin:

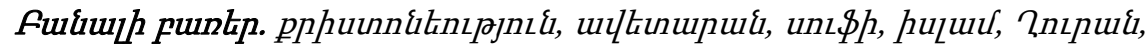

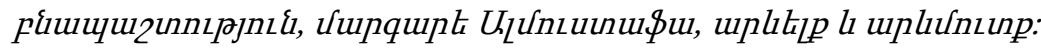

